\title{
MARK MANOLOPOULOS
}

Monash University

\section{Paolo Diego Bubbio \& Philip Andrew Quadrio (eds). The Relationship of Philosophy to Religion Today. Cambridge Scholars Publishing, 2011.}

This collection of essays from a variety of leading and promising thinkers has several things going for it. Stylistically, the texts are clearly written and thus refreshingly accessible. Secondly, the editors have included contributions not only from both the analytic and Continental traditions, but also from theistic, atheistic, and agnostic perspectives, so the volume exemplifies an openness to a variety of currents of thought - an inclusivity that we should expect/demand today. And perhaps most importantly, the essays are rigorously argued, engaging, and life-relevant, so that what we have is, in fact, quite an expansive exploration into not just 'one' relationship between philosophy and religion today but into a number of relationships. And so, the book actually lives up to the promise of its title (and perhaps surpasses it in some ways).

To begin with, the most surprising and impressive part of the book for me is the form and content of the editors' Preface. Right from the start, and with a nice stylistic mix of humility and ambition, the editors challenge us thinkers of religion to be more ambitious ourselves, by not just limiting ourselves to traditional philosophico-theological problems (divine non-/existence, the problem of evil, etc.) but of asking (at the risk of 'arrogance'): 'What ought the relationship between philosophy and religion be?' (p. vii). The editors are very clear on the directions they want philosophy of religion to pursue today (and tomorrow): they speak in particular of the 'political' and 'socio-political' several times throughout the rest of the Preface, as well as referring to 'the symbolic and regulative dimensions of religious life, the existential and cultural import of religion, and the question of religion and politics' (p. ix) expansive, indeed. (The question of the relationship between religion and the political shall recur throughout this review.)

I will say a thing or two to say about all the papers, but will have more to say about the contributions that I myself find most relevant, particularly in terms of the most essential and urgent relationships that philosophy is beginning to have - and should have - with religion. The first essay is exemplary in this regard. Matheson Russell's 'Philosophy 
of Religion in a Secular Age: Some Programmatic Reflections' begins by offering a concise overview of the four basic directions or categories of philosophical thinking of religion: metaphysical, epistemological, philosophico-theological, and philosophico-anthropological. Russell offers a nuanced critique, one with which I am in agreement, e.g., that philosophy of religion has 'become increasingly abstract and technical' (p. 13). The overview alone is impressive, but then the author goes on to situate the various strata in relation to their broader socio-intellectual contexts, with an emphasis on their relationships to secularity. Confirming the thoughts and aspirations of the editors, Russell insists upon the need that philosophy of religion consider its relation to its 'political, social and cultural dimensions': this phrase (and its variations) is repeated throughout the paper. And I was particularly encouraged to note that he cites one particular (and crucial) aspect of this contextualization: 'the adoption of capitalist modes of production, and the development of concomitant forms of socialization and individuation.' (p. 12) (Inspired and informed by the likes of Slavoz Žižek, Antonio Negri, Alain Badiou, and others, thinkers of religion are today beginning to critique capitalism.) The next piece is John Bishop's 'Philosophy and Religious Commitment'. This is a solid piece, which is no surprise, given that the author is a wellestablished figure in contemporary philosophy of religion. In this essay, Bishop begins by convincingly dismantling elements of Alvin Plantinga's 'Reformed epistemology', before outlining a 'modest fideism' influenced by William James and developed by Bishop.

The third contribution is Paul Crittenden's 'Faith In Keeping With Reason: A Critique of the Regensburg Address'. The papal Address (delivered in 2006), which appears to be a strong affirmation of the relationship between rationality and divinity, is critiqued from the outset and along various fronts, e.g., the Pope's attempt to portray a strong link between biblical faith and reason; his construction of a wider gap between Islamic and Christian thought than what may be the case; etc. Crittenden thus effectively weakens the papal argument in a way that is both rigorous and enjoyable. But perhaps what I found most engaging about the piece is what I perceive as an absolutely critical task for both philosophy in general and for philosophy of religion today (and tomorrow): of the need for a revised/expanded figuration of reason, one that avoids, one the one hand, a narrow yet bloated scientistic-instrumentalistic hyperrationalism, and, on the other hand, an impotent reason diluted by a host of excesses (hyper-relativism, over-contextualism, an excessive 
emphasis on difference and otherness, etc.), thus denying reason its force and universality. Crittenden cites the likes of Edmund Husserl, Ludwig Wittgenstein, and Jürgen Habermas as thinkers contributing to the reconception of reason (p. 70).

The next contribution is Kevin Hart's 'Contemplation: Beyond and Behind. This is a typically brilliant piece of work from Hart, with all the hallmarks: a careful retracing of a concept over the centuries, an expansive/encyclopaedic knowledge of the subject-matter, and of course, beautiful prose. But just as this essay is the most beautiful piece in the collection, it is also perhaps the most abstract/removed when it comes to its relation to the rest of the volume - though Hart's text certainly has a lot to say about the continuing relationship of contemplation to theology and philosophy.

The fifth essay is Graham Oppy's "New Atheism” versus "Christian Nationalism": this text also exemplifies the talents of its author: clearly written, thoroughly researched, rigorously argued with all the necessary provisions, qualifications, and nuances ... in sum, a 'nononsense' approach to thinking religion - which should surely be one of the defining characteristics of philosophy of religion today. This piece explores the 'New Atheist' attack on religion, and it is refreshing - even heartwarming - to observe an atheist with a fierce intellect undermining the excessive claims of the New Atheists. Of course, one may find objections with the essay - and Michael Levine certainly does. 'New Atheism, Old Atheism and the Rationality of Religious Belief' is quite a tour de force, somewhat reminiscent of Nietzsche (which is a good thing), but risking a condescension which should have no place in philosophy or philosophy of religion today; e.g., Levine construes philosophy of religion's relation to 'mainstream philosophy' as 'a quaint and poor relation' or 'an irrelevant anachronism' (p. 157). As to who is (more) 'right' would require an extended response, but one way in which I would summarize this most engaging debate is that Oppy may be too forgiving, whilst Levine may be too severe. (I would also contend that philosophy of religion today should re-cast this particular debate in the following way: New Atheism is dogmatic, which makes it nothing new, whilst religion is guilty of some of the charges made by New Atheism, and must be re-figured or even re-made as an open, minimalist - and, yes, rational - faith, which is/would be something new.)

The seventh chapter is 'Religious Reasons in Political Debate: Jeffrey Stout and the Tradition of Democracy' by Anthony J. Langlois. Taking 
up the theme of religion and politics called upon by the book's editors and Russell, Langlois explores this relationship in the context of liberal democracy. As the chapter title indicates, he outlines and evaluates the work of Jeffrey Stout, who wrote the landmark work, Democracy and Tradition (2004). (I myself find it increasingly difficult to defend liberal democracy - particularly in its capitalist manifestation - in the wake of ecological, financial, and a multitude of other crises.) The essay is another solid piece of scholarship. The final essay is Douglas Pratt's 'Religious Identity and the Denial of Alterity: Plurality and the Problem of Exclusivim. The question of religious diversity should certainly be considered when exploring the relationship/s of philosophy to religion today, so this is a welcomed contribution. But what stands out about this text on this topic is that it offers a nuanced understanding of exclusivism: that it should be perceived as being located on a 'continuum' with its 'competing' categories of inclusivism and pluralism (p. 202), and of distinguishing between subtler/more sophisticated forms of exclusivism from exclusivistic extremism (p. 203). Once again, this essay is characterized by the essential features of good scholarship and reflection.

Of course, The Relationship of Philosophy to Religion Today is not nor does it pretend to be - an exhaustive exploration into all of the actual or possible relationships. But it is certainly encouraging to note that the work signals some of the most relevant (and interesting) directions. (As for myself, two particular directions resonate most sharply: the need for a re-figured reason, one that is simultaneously humble and ambitious and informed by a certain openness to faith; and the articulation of how this faith and reason may contribute to much-needed socio-political change.) I strongly recommend this book for anyone interested in philosophy of religion. 